\title{
Bahasa Indonesia Vocabulary Acquisition on a Five-Year-Old Refugee
}

\author{
Lilis Sulistyowati \\ Universitas Islam Negeri Syarif Hidayatullah Jakarta \\ Jl. Ir. H. Juanda No. 95 Ciputat 15412 Jakarta-Indonesia \\ lilissulistyowati04@gmail.com \\ Fahriany \\ Universitas Islam Negeri Syarif Hidayatullah Jakarta \\ Jl. Ir. H. Juanda No. 95 Ciputat 15412 Jakarta-Indonesia \\ fahriany@uinjkt.ac.id \\ Nurhalimah \\ Universitas Islam Negeri Syarif Hidayatullah Jakarta \\ Jl. Ir. H. Juanda No. 95 Ciputat 15412 Jakarta-Indonesia \\ nh.nurhalimah10@gmail.com
}

\begin{abstract}
The paper attempts to answer the questions on the total of Bahasa Indonesia vocabulary that Mazen Abdu Daud has acquired and mastered from the first time he has been following the preparation class for almost four months. This is a qualitative study. It is conducted in a UNHCR's learning center in Ciputat, Jakarta. It has been seen as potentially significant for some main reasons. First, this study draws attention to give an understanding about forced displace person including refugee and asylum seeker. The description of presence needs life and how Bahasa Indonesia is important for them. Second, it offers readers an overview of many refugees in Jakarta Greater area about their country, culture, and history of life. Then, it provides detail information about vocabulary acquisition of Mazen. Concurrently, this study will contribute to give an overview of the refugee education experiences in Indonesia as a transit country, especially who live in Jakarta Greater area. And the last, this study offers unique insight into how refugees adapt to the community in the scope of displacement, marginalization, loneliness, and socialization in the host culture. Such findings will inform teachers, school officials, and policymakers as they consider new ways to assist newly arrived immigrant, including refugees and asylum seekers. This study also contributes to studies on language acquisition process.
\end{abstract}

Keywords: acquisition, refugee, bilingualism, qualitative 


\begin{abstract}
Abstrak
Penelitian ini berupaya menjawab pertanyaan tentang total kosakata Bahasa Indonesia yang diperoleh dan dikuasai Mazen sejak pertama kali mengikuti kelas persiapan selama hampir empat bulan. Penelitian adalah penelitian kualitatif. Penelitian ini dilakukan di pusat pembelajaran UNHCR di Ciputat, Jakarta. Penelitian ini terlihat potensi signifikan untuk beberapa alasan utama. Pertama, penelitian ini menarik perhatian dalam memberikan pemahaman tentang orang yang dipindahkan secara paksa termasuk pengungsi dan pencari suaka. Deskripsi tentang kebutuhan untuk hidup dan bagaimana Bahasa Indonesia berperan penting bagi mereka. Kedua, menawarkan kepada pembaca gambaran dari pengungsi-pengungsi yang tinggal di wilayah Jabodetabek tentang negara, budaya, dan sejarah hidup mereka. Kemudian, penelitian ini memberikan informasi detail tentang akuisisi kosa kata oleh Mazen Abdu Daud. Bersamaan dengan itu, penelitian ini akan berkontribusi untuk memberikan gambaran tentang pengalaman pendidikan pengungsi di Indonesia sebagai negara transit, terutama di wilayah Jabodetabek. Dan yang terakhir, penelitian ini menawarkan wawasan unik tentang bagaimana pengungsi beradaptasi dengan masyarakat dalam lingkup perpindahan, marginalisasi, kesepian, dan sosialisasi dalam budaya tuan rumah. Temuan semacam itu akan memberi informasi kepada guru, pejabat sekolah, serta pembuat kebijakan ketika mereka mempertimbangkan cara-cara baru untuk membantu imigran yang baru tiba, termasuk para pengungsi dan pencari suaka. Studi ini juga berkontribusi pada studi tentang proses akuisisi bahasa
\end{abstract}

Kata Kunci: pemerolehan, pengungsi, bilingualisme, kualitatif

\section{Introduction}

At the start of this research, I have been working as an education officer at one of a learning center for refugee at Jakarta area for almost two years. I am working under the United Nation High Commissioner for Refugees (UNHCR) on refugee's project. For many years, UNHCR makes coordination and elaborateswith Indonesia government counterparts. ${ }^{1}$ This coordination particularly conducts to Ministry of Foreign Affairs, the Coordinating Ministry for Political, Legal and Security Affairs, the Ministry of Law and Human Rights. These are also including the Directorate General of Immigration and the Ministry of Home Affairs to provide good protection, support and identify comprehensive solutions for a person under UNHCR's mandate.

Furthermore, UNHCR also engages with international, NGO, and civil society partners to implement the protection for

${ }^{1}$ Ali, M. (2015). Asylum Seekers and Refugees in Indonesia: Problems and Potentials. Open Journal System, 1-22. refugee that include UN agencies, Church World Service (CWS). Besides, UNHCR's implementing partners involved in assistance programs, as well as operational partner including some NGO international such as the Indonesian Red Cross, International Organization for Migration (IOM), Jesuit Refugee Service (JRS), and the National Human Rights Commission. This collaboration of all NGO is aimed to assist the Government of Indonesia, ensuring the effective protection of refugees, asylumseekers, and stateless persons. ${ }^{2}$

For many years, Indonesia becomes a transit country for refugee and asylum seekers, although Indonesia is not a part of the signing of the 1951 Refugee Convention. ${ }^{3}$ In fact, there are over 14.000 refugees in

${ }^{2}$ UNHCR,I.'FactsheetInd onesia' .2016. Retrieved from https://www.unhcr.org/id/wp-content/ uploads/sites/42/2017/05/Indonesia-Fact-SheetOctober-2016.pdf

${ }^{3}$ Ali, M. (2015). Asylum Seekers and Refugees in Indonesia: Problems and Potentials. Open Journal System, 1-22. 
Indonesia. ${ }^{4}$ Due to this condition, it needs an agreement to Indonesia Government. After long-awaited, Presidential Regulation (Perpres) No 125 of 2016 on the Treatment of Refugees and Asylum Seekers in Indonesia, signed by President JokoWidodo on 31 December 2016becomes a regulation which organizes the position towards refugees and asylum seekers in Indonesia. ${ }^{5}$ By the agreement of its government, UNHCR has authorizationto help, protect, and find the solution for them. An immigration regulation ensures that refugees and asylum seekers have access to UNHCR, and allows them to stay temporally in the country until their refugee status can be confirmedan appropriate solution can be found for them. ${ }^{6}$

There is a huge amount of refugee around the world. ${ }^{7}$ UNHCR pursues a range of options for refugee based on their different situation. The treatments include the resettlement to a third country for the most vulnerable, family reunification, voluntary repatriation to countries of origin, and temporary protection mechanism that focus on vocational training and promoting access to labor scheme, particularly joint projects with members of host communities, as well as income-generating activities. ${ }^{8}$

In a transit country, UNHCR gives an effort to increase the mechanism of selfreliance. Self-reliance defines as the ability to rely on all of the resources (physical,

${ }^{4}$ Hirsch, A. (2018). Afterthe Boats Have Stopped: Refugees stranded in Indonesia and Australia's containment policies. Journal of Refugee Studies, 1-5.

${ }^{5}$ Missbach, A., (2018). Stalemate: Refugees in Indonesia -Presidential Regulation No 125 of 2016. CILIS, 1-28.

${ }^{6}$ Missbach, A., Ibid

${ }^{7}$ Pathak, \&. S. (2018, March). Refugee Crises around the World Today. Annual Research Journal of SCMS, Pune, 6, 18-31.

${ }^{8}$ Lego, J. B. (2012). Protecting and Assisting Refugee and Asylum Seekers in Malaysia: The Role of UNHCR, Informal Mechanism and The Humanitarian Exception. Journal of political science and sociology, 75-99. social and natural capital or asset) from an individual, household or community to fulfill their own basic needs. ${ }^{9}$ Thoseareincluded protection, food, water, shelter, personal safety, health, and education. In Indonesia and other countries as a hosting country for refugee, they also conduct many programs in collaborating with some NGO (international and local) to realize the self-reliance goal. ${ }^{10}$ The implementation of education conducted by UNHCR includes the strengthening of institutional commitment and preparedness, regarding policy, staffing arrangements and training, and funding.

In education, UNHCR continues to implement educational programs. For example, the program was conducted in Syrian refugee. Many Syrian refugee children will be referred to language supports, such as ESL programs in their districts. ${ }^{11}$ This research is also a folk bilingualism. Because the Syrian refugees have to master the second language to obtain the requirement in studying in public school in the third country. In Indonesia, the implementation of education is conducted through the Catholic Relief Service (CRS), PKPU HI, and Dompet Dhuafa. Refugees' children have access to primary and secondary education in Indonesia public school. So, many learning centers are built as a place for the refugee to study. They can learn the English language, Indonesian language, Mathematics, Science, Computer, and life skills such as training of handphone service, make soap, make handicraft from plastics, etc. It is also the place for children to

${ }^{9}$ Frank, A. (2014, September). The Self Reliance Strategy And Refugee Livelihoods: Evidence From Oruchinga Refugee Settlement, South Western Uganda. International Journal of Research In Social Sciences, 4, 59-65.

${ }^{10}$ Frank, A., Ibid

${ }^{11}$ Wofford, M. C. (2018). A human right to literacy education: Implications for serving Syrian refugee children. International Journal of SpeechLanguage Pathology , 182-190. 
be prepared forentering local public school such as primary school and accelerated school (PKBM/PusatKegiatanBelajarMasyarakat/ Society Education Center).

For preparation classes to enter the public school, Dompet Dhuafa conducts class in the learning center. It has three levels based on their range of age. Level $\mathrm{A}$ is for 4-5 years old, B for 6-7 years old, and C for 8-15 years old. The A and B levels are prepared for entering "Sekolah Dasar" or primary school and $C$ level for PKBM.

The main requirements for entering public school is the students has to speak up and write in BahasaIndonesia. So, the main subjects in the preparation school are Bahasa Indonesia and Mathematics subjects. All of the students in the preparation school are refugees. They are so come from many countries such as Somalian, Yemen, Iran, Afghanistan, etc. On summary, they are forced to learn Bahasa Indonesia to improve their education. They encounter folk bilingualism.

When they arrived in Indonesia for the first time, all most of them just speak their "mother" or native languages. It also happens to Mazen Daud. He just speaks in Somalian as Somali child. The core is how he adapts to the folk bilingualism that force to him. Then, this article will explain how many Bahasa Indonesia vocabularies that Mazen acquires from the first time he has been following in the preparation class in several months.

\section{Theoretical Framework}

\section{a. Second Language Acquisition}

Second language acquisition (SLA) is defined as the learning of any language in addition to the mother tongue. The mother tongue as a first language alsouseful as an introduction to a second language because it can be acquiredafter having received the competences in a first language. Ellis argued that the second language is not only the language learned or succeeding one's mother tongue, but other languages, the third or fourth language is part of the second language acquisition. ${ }^{12} \mathrm{By}$ acquiring another or additional languages, an individual requires passingthe stages as the way as same as in learning their first language. In learning language, some people find difficulty, especially adult. Moreover, it is essential for second language learners accepting an enormous amount of language exposure that given for them to learn it. ${ }^{13}$

Many people decide to learn second or more language for many reasons. For instance, they want to improve their knowledge, expanding to get a better job, communicating to society.Learning the second language requires time, effort, and organization for the individual to learn the language. One needs to be fluent in the native language also.

Generally, learning the mother tongue is not difficult, but rather, the skills in learning other language varies for the individual, their attitudes towards the language and motivation.The second language can be acquired either formal or informal. To acquire formally can get in schools and language coursesand through walking on the streets and interacting with the community is a way to acquire second language informally. ${ }^{14}$ Besides, globalization makes people knowing or learning more different language and culture every daythrough many media such as social media, television, internet, etc.

${ }^{12}$ Ellis, R. (1997). Second language acquisition. Oxford: Oxford University Press. p.3.

${ }^{13}$ Krashen, S. (1981). Second Language Acquisition and Second Language Learning. Pergamon Inc. p.19.

${ }^{14}$ Darko, A. A. (2010). Language Acquisition: Acquiring Languages beyond knowledge in first language. Journal of Multilingual and Multicultural Development, 97-134. 
The benefit of acquiring the second or third language is important because it can improve theknowledge and increase opportunities in employment. ${ }^{15}$ Given this, it is therefore very essential to be aware of acquiringa second language and its contribution to peoples educational development in general.

\section{b. Bilingualism}

Bilingualism is defined as "knowing" two or more languages. Weir states that "bilingualism is considered as mastering two languages equally". ${ }^{16}$ According to Moradi, bilingualism can be defined as the use of at least two languages, either by a group of speakers or by an individual. ${ }^{17}$ Then in using the languages, for many bilinguals, they use one language is spoken at home and tends to be in informal registers, whilethe other is spoken in school with an extensive academic vocabulary, but this does not reflect a deficiency, merely a different area of knowledge. Then, it is rare to find bilinguals with a balanced or equal ability in their language usage. One language is often used more than the other language, and this can change with time. It is rare to find bilinguals with a balanced or equal ability in their language usage. One language is often used more than the other language, and this can change with time.

There are many types of bilingualism: ${ }^{18}$

1. Early and late bilingualism. It considers the age when mastering the languages.

${ }^{15}$ Martha, G. A. (2018). The Benefits of Second Language Learning. ResearchGate-Modern Language Journal, 408-451.

${ }^{16}$ Maftoon, P. (2011). Who is Bilingual. ResearchGatejournal of Educational Research, 323- 326.

${ }^{17}$ Moradi, H. (2014). An Investigation through Different Types of Bilinguals and Bilingualism. International Journal of Humanities $\mathcal{E}$ Social Science Studies (IJHSSS), I(II), 107-112.

${ }^{18}$ Moradi, H., Ibid.
2. Balance and dominant bilingualism. These regard to the relation between the fluency and the proficiency among the languages used by the bilingual.

3. The compound, Coordinate, and Subordinate Bilinguals. These consider dealing with the properties of how two or more linguistic codes are organized and stored by individuals.

4. Folk and Elite Bilinguals. These depend on variables such as cultural identity and language usage.

5. Additive Bilinguals and Subtractive Bilinguals. These regarding on how one's L2 influences the retention of one's L1.

In this paper, folk bilingualism distinguishes as the result of the contact of ethnic groups who have to become bilingual involuntarily to survive; here they do not have a choice, they have to learn the language of the setting where they live. ${ }^{19}$

\section{c. Vocabulary}

Learning vocabulary is one of the vital partsof learning a language because vocabulary is the language itself. ${ }^{20}$ People use vocabulary in applying the language, whether in spoken or the written. Sometimes, we do not need structure. In contrast, we only need words or vocabularies to convey our meaning to others. For that reason, the Nation realized that vocabulary acquisition is essential for language use. ${ }^{21}$

There are some definitions to give meaning in vocabulary. Murcia said that "Vocabulary can be defined, roughly, as the

${ }^{19}$ Guerrero, C. H. (2010). Elite Vs. Folk Bilingualism: The Mismatch between Theories and Educational and Social Conditions. ERIC , 165-179.

${ }^{20}$ Alqahtani, M. (2015). The Importanceof Vocsbulary in Languageand Howtobe Taught. International Journal of Teaching and Education, III, 21-35.

${ }^{21}$ Nation, I. S. Learning Vocabulary in Another Language. Cambridge: Cambridge University Press. 2001, p.23. 
words we teach in the foreign language" ${ }^{22}$ Then, Read argued that "Vocabulary has been defined in separated meaning such as the word". ${ }^{23}$ Moreover, in another definition, Schmitt said the meaning of vocabulary is words, a formulation that is admirably adequate for the layperson." ${ }^{24}$ From the statements above, it shows that vocabulary is words that are related to the meaning of the word and the way to use them in communication.

\section{d. Refugee}

Because of war, many people have to live in conflict, crisis, and persecution. Some civil try to defend on their country,butothersflew out to another country seeking for protection. They come from many conflict countries and live in another country as refugees and asylum seekers. According to UNHCR's data, there are 65.6 million refugees, internally displaced persons (IDPs), and asylum seekers all over the world. ${ }^{25}$

Who are Internally Displaced People (IDP)? "People forced who flee their homes, but unlike refugee, they never cross an international border. ${ }^{26}$ These individuals move to seek safety such nearby towns, schools, settlements, internal camps, even forests, and fields. However, IDPs are not protected by international law or eligible to receive many types of aid because they arelegal under the protection of their government. Meanwhile, asylum seekers are people who are expelled from their country

${ }^{22}$ Murcia, M. C. Teaching English as a Second Language or Foreign Language. Massachusetts: Heinle Publisher.1991, p.4.

${ }^{23}$ Read, J. Assessing Vocabulary. Cambridge: Cambridge University Press.2000, p.16.

${ }^{24}$ Schimtt, N. Vocabulary in Language Teaching. Cambridge: Cambridge University Press. 2000. p.5.

${ }^{25}$ Pathak, \&. S. (2018, March). Refugee Crises around the World Today. Annual Research Journal of SCMS, Pune, 6, 18-31.

${ }^{26}$ Akhunzada, W. e. (2015). Internally Displaced Persons (IDPS); Anxiety and Depression. ResearchGate, 3, 337-342. and are seeking asylum in other countries and have not received a decision on refugee status.

Then, the definition ofa refugee is defined. "A refugee is a person who forced to get out from his or her country because of persecution, war, or violence.". ${ }^{27}$ There are many reasons for a refugee fleeing their countries such as war and ethnic, tribal, and religious violence. Most ofthe refugees have a well-founded having traumatic and fear of thispersecution. They go to another country to get civilization to the third country which can give them safety and nationality.

Regarding the 1951 Convention on Refugee Status and the 1967 Protocol: ${ }^{28}$

"A refugee is a person who fears that he/she will become a victim. Arefugee defines as a person who feel fears that he or she will become a victim of torture on the ground of race, religion, nationality, membership of a particular social group, or because of his political opinion, then outside his home country and may or may not wish to return to his home country for reasons of being a victim of persecution."

Who is an asylum seeker? The asylum seeker is a people who flee from their own country and try to get sanctuary in another country; they apply themselves for asylum. An asylum seeker must proof and demonstrate that his or her fear of persecution in his or her home country is well-founded. Then, their status will be changed to refugee if they registered by UNHCR as refugees. Their condition will be better, and they will receive legal protection

${ }^{27}$ UNHCR. (2011). UNHCR Ressetlement Handbook. Geneva: Imprimeri Centrale S.A. Retrieved from https://cms.emergency.unhcr.org/ documents/11982/44343/UNHCR\%2C+Resettlement+ Handbook\%2C+2011/

${ }^{28}$ UNHCR. (1954). Journal of International Law, 193. Retrieved from http://www.unhcr.org/4bc2ddeb9. pdf 
and material assistance if they are recognized as a refugee.

\section{Findings and Discussion}

This research was conducted in the qualitative approach. The researcher chose a case study. Then, she decided to collect the data by doing interviews, observation in his class, and using teachers' diary on his achievement during his study from September until December 2018. This research was not aimed to find the result. It just described further research.

\section{a. The Participant}

The subject of the data was a Somalian child who speaks in Somalian and forced to speak Bahasa Indonesia in age five years. He uses Somalian language in the family. Then, he uses Bahasa Indonesia at learning center course. Meanwhile, he uses Bahasa Indonesia in the environment since he lives in Indonesia. He has to learn Bahasa Indonesia to communicate with his refugee's friends who come from several countries and his Indonesian friends surrounding his house. The researcher took him in the private course as a sample.

\section{b. Data Collection Procedure}

The ways of collecting data were in a variety of ways such as a) interviews to the object (Mazen Abdul Wadud), his father, and his teachers, b) observation in his class and c) using teachers' diary on his achievement during his study from September until December 2018.

\section{c. Data Analysis Technique}

In this analysis, it was conducted by ongoing analysis and after collecting the entire data. ${ }^{29}$ Purpose an analysis model consists of three concurrent steps. They are data reduction, data display, conclusion drawing, or verification. The procedures are:

${ }^{29}$ Miles, B. M. Qualitative data analysis: a method source book (3rd edition). Arizona: Sage.2014 p. 109. (a) identify the teachers' diaryon the object's achievement (b) observe in the class (c) analyze bilingualchild's ability through the interviews (Mazen, parents, and teachers). The data of this study were taken from the interview, dairy,and observation. In this study, the researcher firstly tried interview to get preliminary information on the implementation of the bilingual child in his daily life. After that, the teachers' diary on Bahasa Indonesia was observed. This was intended to crosscheck between observed and the data interviewed.

\section{d. Finding}

Based on the empirical data from the father and teachers, this bilingual child was categorized into active bilinguals. $\mathrm{He}$ can use languages actively in speaking and applying those languages in activities in class and makes conversation with his friends from another country. The refugees only used Bahasa Indonesia in class preparation. They were not allowed to use their native language, even English. However, they used another language or maybe their native language in their preference. They usually found it difficult difficult to use the second or third language. For example, Mazen's father explained, "It is hard for children that living in a country that they feel like they are born in this country, but their parents come from another country. They still bring their habitual nature life. In this statement, Mazen communicates the deliberate choice that many children of refugees make to stay connected to their parents' countries of origin and inherently languages of origin.

Mazen's father explained that his family uses Somalian language to maintain "their" language to stay connected to "their" family. But, he stressed that Bahasa Indonesia was essential to speak to the teachers and his friends in course because his friends come from many countries with 
their native language such as Farsi language from Afghanistan, Urdu language from Iran, Arabic language Yemen, etc. for Mazen's activities.

The following is the total and kinds of vocabularymastered by Mazen

\begin{tabular}{|c|c|c|c|}
\hline No & Indicator & Kinds & Total \\
\hline 1. & $\begin{array}{l}\text { Mentioning his } \\
\text { identity }\end{array}$ & $\begin{array}{l}\text { His name, his father } \\
\text { name, his mother } \\
\text { name, his brother } \\
\text { \& sisters name, his } \\
\text { address. }\end{array}$ & 14 \\
\hline 2. & $\begin{array}{l}\text { Memorizing } \\
\text { number 1-5 }\end{array}$ & $1,2,3,4,5$ & 5 \\
\hline 3. & $\begin{array}{l}\text { Memorizing } \\
\text { things on body }\end{array}$ & $\begin{array}{l}\text { Shirt, T-shirt, skirt, } \\
\text { short, hat, glasses, } \\
\text { veil, sandals, shoes }\end{array}$ & 9 \\
\hline 4. & $\begin{array}{l}\text { Telling about } \\
\text { activities at } \\
\text { home }\end{array}$ & $\begin{array}{l}\text { Sleep, take a bath, } \\
\text { eat, drink, tooth } \\
\text { brush }\end{array}$ & 6 \\
\hline 5. & $\begin{array}{l}\text { Asking } \\
\text { permission }\end{array}$ & $\begin{array}{l}\text { Asking permission to } \\
\text { toilet, drink, eat }\end{array}$ & 3 \\
\hline 6. & $\begin{array}{l}\text { Doing the } \\
\text { instruction } \\
\text { given by the } \\
\text { teacher }\end{array}$ & $\begin{array}{l}\text { Sit, tidy up, listen, } \\
\text { look, shut up }\end{array}$ & 5 \\
\hline 7. & $\begin{array}{l}\text { Mentioning } \\
\text { transportation } \\
\text { vehicles }\end{array}$ & $\begin{array}{l}\text { Car, bicycle, } \\
\text { motorcycle, plane }\end{array}$ & 4 \\
\hline 8. & $\begin{array}{l}\text { Mentioning part } \\
\text { of the body }\end{array}$ & $\begin{array}{l}\text { Eyes, nose, mouth, } \\
\text { hands, legs }\end{array}$ & 5 \\
\hline 9. & $\begin{array}{l}\text { Mentioning } \\
\text { animals living } \\
\text { in sky, land, } \\
\text { water }\end{array}$ & $\begin{array}{l}\text { Birds, butterfly, crabs, } \\
\text { fish, cat, chicken, } \\
\text { rabbit }\end{array}$ & 7 \\
\hline 10. & $\begin{array}{l}\text { Parts of animal } \\
\text { body }\end{array}$ & Head, eye, ear, tail & 4 \\
\hline 11. & $\begin{array}{l}\text { Kinds of } \\
\text { animals' food }\end{array}$ & $\begin{array}{l}\text { Grass, carrot, fish, } \\
\text { rice }\end{array}$ & 4 \\
\hline 12. & $\begin{array}{l}\text { Animal's part } \\
\text { of body for } \\
\text { moving }\end{array}$ & Legs, wings & 2 \\
\hline 13. & $\begin{array}{l}\text { Understanding } \\
\text { types of shapes }\end{array}$ & Circle, cubes, triangle & 3 \\
\hline 14. & $\begin{array}{l}\text { Understanding } \\
\text { primary colors }\end{array}$ & Red, blue, yellow & 3 \\
\hline 15. & $\begin{array}{l}\text { Mentioning } \\
\text { things in the } \\
\text { classrooms }\end{array}$ & $\begin{array}{l}\text { Pencil, book, } \\
\text { sharpener, eraser, } \\
\text { whiteboard }\end{array}$ & 5 \\
\hline 16. & $\begin{array}{l}\text { Memorizing } \\
\text { number 6-10 }\end{array}$ & $6,7,8,9,10$ & 5 \\
\hline
\end{tabular}

\begin{tabular}{|l|l|l|c|}
\hline 17. & $\begin{array}{l}\text { Mentioning } \\
\text { secondary } \\
\text { colors }\end{array}$ & Purple, orange, green & 3 \\
\hline 18. & $\begin{array}{l}\text { Expressing } \\
\text { feelings }\end{array}$ & $\begin{array}{l}\text { Angry, happy, sad, } \\
\text { disappointed, hot, } \\
\text { cold }\end{array}$ & 6 \\
\hline \multicolumn{2}{|l}{ Total } & 90 \\
\hline
\end{tabular}

From the teachers' diary above, it can be concluded that the total of vocabulary mastered by Mazen average 90 vocabularies during September until December on his school. The kinds of vocabulary are mastered in basic level of Bahasa Indonesia. Furthermore, from the Mazen's father in his interview, he said that Mazen also can speak "lo", "gue”, "Bapak", “Jalan”, “jajan”, "beli", "ayo","Sakit", "pergi", "nangis", "Rumah", and "teman". Those words are got through his interaction with his friends at surrounding his home. Mazen can master almost a hundred Bahasa Indonesia words in almost four months.

\section{Conclusion}

The influences of folk bilingualism in refugee to learn Bahasa Indonesia cannot be seen as the refugees' children have been cured of their traumatic lives that happened in their country. When they can adapt to their new places, they can enjoy acquiring other languages. However, for refugee, sometimes they have to learn a new language to survive and continue their life even to improve their study. They also have to make interaction in the transit country with the transit country's language. Unfortunately, language learning and acquiring are not at all a simple task. Most of those who point the finger at migrant language shirkers vastly underestimate the effort involved in language learning. The consensus in applied linguistics is that language learning takes a long time and that the precise duration and outcome as measured in proficiency level are almost impossible to predict as they depend on many factors. Most of which are outside of 
the control of an individual language learner, such as age, level of education, aptitude, teaching program, language proximity, or access to interactional opportunities.

Even though the results from this study did not indicate any statistically significant effects of Bahasa Indonesia language courses on refugees' language development, studies from other fields have shown a positive effect. For instance, after they can master its language, they can continue their study, get the certificate that useful in the third country.

\section{References}

Akhunzada, W. e. (2015). INTERNALLY DISPLACED PERSONS (IDPS); ANXIETY AND DEPRESSION. ResearchGate , 3, 337-342.

Ali, M. (2015). Asylum Seekers and Refugeesin Indonesia: Problems and Potentials. Open Journal System , 1-22.

Alqahtani, M. (2015). THE IMPORTANCE OF VOCABULARY IN LANGUAGE AND HOW TO BE TAUGHT. International Journal of Teaching and Education , III, 21-35.

Darko, A. A. (2010). Language Acquisition: Acquiring Languages beyond knowledge in first language. Journal of Multilingual and Multicultural Development, 97-134.

Ellis, R. (1997). Second language acquisition. Oxford: Oxford University Press.

Frank, A. (2014). THE SELF RELIANCE STRATEGY AND REFUGEE LIVELIHOODS: EVIDENCE FROM ORUCHINGA REFUGEE SETTLEMENT, SOUTH WESTERN UGANDA. International Journal of Research In Social Sciences , 4, 59- 65.

Guerrero, C. H. (2010). Elite Vs. Folk Bilingualism: The Mismatch between
Theories and Educational and Social Conditions. ERIC , 165-179.

Hirsch, A. (2018). AFTER THE BOATS HAVE STOPPED: Refugees stranded in Indonesia and Australia's containment policies. Journal of Refugee Studies, $1-5$.

Krashen, S. (1981). Second language acquisition and second language learning. Pergamon Inc.

Lego, J. B. (2012). Protecting and Assisting Refugee and Assylum Seekers in Malaysia: The Role of UNHCR, Informal Mecahanism and The Humaniterian Exception . Journal of political science and sociology, 75-99.

Maftoon, P. (2011). Who is Bilingual. ResearchGate-journal of Educational Research, 323- 326.

Martha, G. A. (2018). The Benefits of Second Language Learning. ResearchGateModern Language Journal , 408-451.

Miles, B. M. (2014). Qualitative data analysis: a method source book (3rd edition). Arizona: Sage.

Missbach, A. .. (2018). Stalemate: Refugees in Indonesia - Presidential Regulation No 125 of 2016. CILIS , 1-28.

Moradi, H. (2014). An Investigation through Different Types of Bilinguals and Bilingualism. International Journal of Humanities \& Social Science Studies (IJHSSS) , I (II), 107112.

Murcia, M. C. (1991). Teaching English as a Second Language or Foreign Language. Massachusetts: Heinle Publisher.

Nation, I. S. (2001). Learning vocabulary in another language. Cambridge: Cambridge University Press.

Pathak, \&. S. (2018). Refugee Crises around the World Today. Annual Research Journal of SCMS, Pune, 6, 18-31.

Read, J. (2000). Assessing Vocabulary. 
106| Hlementitiry Vol. 5 No. 2, July -December 2019

Cambridge: Cambridge University Press.

Rongchai, C. (2014). More Than English: Karen Refugees Negotiating Their Lifestyle in A Cosmopolitan City/A Dissertation. Illinois.

Schimtt, N. (2000). Vocabulary in Language Teaching . Cambridge: Cambridge University Press.

UNHCR. (1954). Journal of International Law, 193.

UNHCR. (2011). UNHCR Ressetlement Handbook. Geneva: Imprimeri Centrale S.A.

UNHCR, I. (2015). 'Factsheet Indonesia'.

Wofford, M. C. (2018). A human right to literacy education: Implications for serving Syrian refugee children. International Journal of SpeechLanguage Pathology , 182- 190. 